\title{
Availability of Facilities and Equipment for Sports Administration at the Local Government Areas of Delta State, Nigeria
}

\author{
Stephen Onojohwevwo Esegine Diejomaoh \\ Physical and Health Education Department, Delta State University, Abraka \\ Emmanuel Akarah \\ Physical and Health Education Department, Delta State University, Abraka \\ Favour Okagbare Tayire \\ Physical and Health Education Department, Delta State University, Abraka
}

Doi:10.5901/ajis.2015.v4n2p307

\begin{abstract}
Sports facilities and equipment are fundamental to sports development and achievements globally. In Nigeria, the responsibility lies with the three tiers of governments (Federal, State and Local Governments) to provide facilities and equipment for sports administration, competitions, recreation and educational purposes. The extent to which sports facilities and equipment are provided at the local government level is not known. Justification for government's heavy spending on sports at the local government area level is also not known. This study was therefore carried out to establish the extent to which sports facilities and equipment are provided for sports development at the local government areas of Delta State, Nigeria. Efforts at providing at the grassroots level, which is their responsibility need to be ascertained in terms of the extent to which they are provided. It is in this regard that this paper examined the extent to which sports facilities and equipment are available towards sports development at the Local Government Areas of Delta State, Nigeria. The study adopted the descriptive survey design. The sample size for the study is 400 determined through the whole sample sampling technique comprised of Local Government Sports Committee members, sports officers in all the Local Education Authorities and Sports Officers in the Ministry of Education offices in the 25 Local Government Areas of Delta State. A self structured questionnaire and checklist were used to elicit data. The results showed that Local Governments of Delta State provided facilities and equipment for soccer, athletics, badminton, volleyball, and general playing field to a high extent while the extent of provision of facilities and equipment for the other sports was low.
\end{abstract}

Keywords: Sports development, Sports facilities, Sports equipment, Sports festivals, Sports budgeting.

\section{Introduction}

Sports have grown globally in proportion to the extent that sports activities are deliberately encouraged within nations. In Nigeria, it is recognized as a tool for national mobilization, cultural reorientation, national integration and unity (Ikhioya, 1996; Onifade, 2000). Sports in Nigeria have become important endeavours so much that its management and development has become the responsibilities of the three tiers of government (Federal, State and Local Governments). Private sector involvement is being wooed and encouraged by the Federal Government (Federal Republic of Nigeria, 2009).

According to the Federal Republic of Nigeria's Sports Policy ( 2009), it is the responsibility of the Local Government Councils to manage the grassrootssports, which cover primary and secondary schools and community sports as well as recreation. The Local Government provides facilities, equipment and programmes for the encouragement of sports. It establishes Local Government Sports Committees, Sports Associations, Sports Clubs and coordinates sport activities at the grassroots level.

The activities of the Local Governments cover the following minimum number of sports; Soccer, Volleyball, Athletics, Gymnastics, Swimming, Handball, Table Tennis, Cricket, Field hockey, Tennis, Badminton, Basketball, Sports for disabled and stadium development for Youth Centre Development. These sporting activities are in line with the Federal Republic of Nigeria policy which aims at creating a social condition that is conducive for physical fitness for all, effective physical functioning of the individual that ensures self-actualization for the citizenry and the development of sports to world class status (Diejomaoh, 2011). 
According to Talabi (1998), the attainment of a world class status in sports is a reflection of the presence of top standard equipment and facilities. He added that most developing countries and Nigeria in particular, wish to arrive at the level of the developed countries sports-wise overnight, but that while developed countries are putting so much into building excellent facilities and providing standard equipment as well as creating conducive environments for their athletes, developing countries seem to lag behind in the provision of the necessary amenities. He further stressed that one area of very poor start is in the provision of standard facilities/equipment while the few provided are either obsolete, not functional or substandard.

In the opinion of Ekpe (2001), it is difficult to separate the standard of sports in a country from the standard of facilities and equipment available. Omoruan (1996) posited that facilities and equipment are the greatest among all factors that affect the growth of a sport. Ogbemudia (2001) emphasized that if Nigeria must attain the desired standards in performance and attain top ratings in the Olympic Games, then the planning and management of sports facilities and equipment must not only be broad based but also be backed-up with adequate provision and maintenance of the available facilities and equipment. Gbinijie (2001) noted that there is the Leviathan dearth of sporting infrastructure and equipment in Nigeria and further emphasized that most Local Government Areas have no playgrounds or fields, not to talk of a stadium. He then wondered about the possibility of developing sports at the grassroots level in the absence of swimming pools, hockey fields, basketball courts, soccer pitches and cricket pitches if talents are expected to be groomed at the grassroots level. Perhaps, it is in this direction that Jeroh (2005) stated that the major problem in administration of sports in Nigeria is the dearth of sports facilities and equipment.

It is in these regards that this study seeks to carry out an evaluative survey of the level of facilities and equipment provided at the Local Government Areas of Delta State, Nigeria for sports development.

\section{2. $\quad$ Research Questions}

The following research questions were generated to guide this study:

i. To what extent are sports facilities provided for sports development at the Local Government Areas of Delta State, Nigeria?

ii. To what extent are sports equipment provided for sports development at the Local Government Areas of Delta State, Nigeria?

\section{Purpose of the Study}

The purpose of the study is to determine the level of available sports facilities and equipment provided at the Local Government Areas of Delta State, Nigeria with a view to ascertaining their adequacy for sports development at the grassroots level in Nigeria.

\section{Method}

The study adopted the descriptive survey design. The target population for this study is 400 made up of 250 members of the Local Government Sports Committees; 75 sports officers in the Local Education Authorities (LEA) and 75 sports officers in the Ministry of Education Office in the 25 Local Government Areas of Delta State, Nigeria. The sample size for the study is comprised of the entire population (400) determined through the whole sample sampling technique due to the fact that the size is small and could be managed in the study (Whawo, 1992 and Peretomode and Ibeh, 1992).

The instruments used for the study consisted of a 25 item self structured questionnaire which face and content validity were ascertained by three experts from the Department of Physical and Health Education, Delta State University, Abraka. They were requested to check the items on the questionnaire for clarity, suitability and adequacy. A reliability index (r) of 0.86 was established with the Pearson's Product Moment correlation.

A checklist was drawn from the benchmark of requirements (Bendel State Sports Edict, 1979 adopted by Delta State 1991) for sports facilities and equipment of each sport which the Local Government Area is expected to provide at the grassroots. The data generated for the study were analysed using simple percentages. 


\section{Benchmark for Local Government Sports Facilities and Equipment}

Table 1: Minimum Facilities and Equipment Requirement for each Location

\begin{tabular}{|c|c|c|c|}
\hline S/N & Sport & Facility & Number of equipment required \\
\hline 1 & Soccer & 1 pitch & 6 soccer balls, 22 pairs of soccer boots, 21 pairs of goal nets, 1 white, 2 sets of plying jerseys \\
\hline 2 & Athletics & 400m Oval & $\begin{array}{l}6 \text { pairs of spike shoes, } 6 \text { relay batons, } 2 \text { pairs of high jump stand, } 2 \text { crossbars, } 3 \text { measuring tapes, } \\
3 \text { shot put, } 3 \text { discuss, } 2 \text { javelin, } 6 \text { stop watches, } 2 \text { rolls of breast tapes, } 100 \text { hurdle stand }\end{array}$ \\
\hline 3 & Baseball & 1 Court & 6 basketball nets, 2 backboard, 2 pairs of rings and nets \\
\hline 4 & Volleyball & 1 Court & 2 volleyball nets, 6 volleyballs, 12 pairs of trunk and vest \\
\hline 5 & Table Tennis & 1 Hall & 4 bats, 1 net, 1 table, 2 table tennis balls \\
\hline 6 & Gymnastics & Gymnasium & $\begin{array}{l}10 \text { gym mats, } 2 \text { beam, } 2 \text { vaulting box, } 10 \text { dumb bell, } 2 \text { benches, } 10 \text { loops, } 1 \text { parallel and } 1 \\
\text { horizontal bar }\end{array}$ \\
\hline 7 & Hockey & 1 pitch & 22 sticks, 2 pairs of protective pads, 2 goal nets \\
\hline 8 & Lawn Tennis & 1 Court & 4 rackets, 1 tin of balls, 2 nets, 10 pairs of canvas shoes \\
\hline 9 & Badminton & 1 Court & 4 rackets, 1 tin of shuttle corks, 2 nets, and 2 pairs of net stands \\
\hline 10 & Cricket & I Cricket Oval & 2 bats, 2 balls, 2 wickets \\
\hline 11 & Swimming & I swimming pool & 6 swimming suits, 6 floaters, 6 towels \\
\hline 12 & Disabled Sports & $1 \mathrm{Hall}$ & Modified supplies for disabled sports \\
\hline 13 & Youth Centre & 1Multipurpose Hall & Different supplies for various vocation/recreational sport \\
\hline
\end{tabular}

Source: Bendel State Sports Edict, 1979.

Table 2: Analysis of Responses on Provision of Sports Facilities by the Local Government Councils in Delta State, Nigeria

\begin{tabular}{|c|c|c|c|c|c|c|c|}
\hline \multirow[b]{3}{*}{$S / N$} & \multirow[b]{3}{*}{ Sport facility provided } & \multicolumn{6}{|c|}{$\mathrm{N}=400$} \\
\hline & & \multicolumn{6}{|c|}{ Frequency Count of Responses ( ) \% } \\
\hline & & \multicolumn{2}{|r|}{ Nil } & \multicolumn{2}{|c|}{$1-4$} & \multicolumn{2}{|c|}{ Above 4} \\
\hline & & No. & $\%$ & No. & $\%$ & No. & $\%$ \\
\hline 1 & Soccer pitch & 18 & $(4.5)$ & 141 & $(35.3)$ & 241 & $(60.3)$ \\
\hline 2 & General play field & 59 & $(14.8)$ & 167 & $(41.8)$ & 174 & (43.5) \\
\hline 3 & Basketball court & 208 & $(52.0)$ & 71 & $(17.8)$ & 121 & (30.3) \\
\hline 4 & Volleyball & 156 & $(39.0)$ & 85 & (21.3) & 159 & (39.8) \\
\hline 5 & Athletics Track and Field & 121 & (30.3) & 131 & (32.8) & 148 & (37.0) \\
\hline 6 & Gymnasium & 383 & (95.8) & 9 & $(2.3)$ & 8 & $(2.0)$ \\
\hline 7 & Swimming Pool & 296 & $(74.0)$ & 33 & (8.3) & 71 & $(17.8)$ \\
\hline 8 & Lawn Tennis Court & 337 & (84.3) & 34 & (8.5) & 29 & (7.3) \\
\hline 9 & Badminton & 399 & (99.8) & 16 & $(0.3)$ & - & - \\
\hline 10 & Hockey Pitch & 400 & $(100.0)$ & - & - & - & - \\
\hline 11 & Cricket Pitch & 400 & $(100.0)$ & - & - & - & - \\
\hline 12 & Facility for Disabled Sports & 399 & $(99.8)$ & & $(0.3)$ & - & - \\
\hline 13 & Youth Centre & 104 & $(26.0)$ & 136 & $(34.0)$ & 160 & $(40.0)$ \\
\hline 14 & Stadium & 386 & $(96.0)$ & 15 & $(3.8)$ & 1 & $(0.3)$ \\
\hline
\end{tabular}

Table 2 reveals that the provision of soccer pitches is 141 and 241 representing $35.5 \%$ and $60.3 \%$ respectively who responded to the checklist that 1-4 soccer pitches and above 4 soccer pitches are provided by the Local Government Areas of Delta State while 18 respondents representing 4.5\% responded that there are no provision of soccer pitches. 167 and 174 respondents representing $41.8 \%$ and $43.9 \%$ affirmed that $1-4$ and above 4 general playing fields are provided by the Local Government Areas of Delta State.A significant 208 responses representing $52.0 \%$ of the population responded that there are no provisions of basketball courts.However, 71 and 121 respondents representing $17.8 \%$ and $30 \%$ responded that there arebetween 1-4and above4 courts respectively.

For the provision of volleyball courts, 156 respondents representing $39.0 \%$ responded that volleyball courts were not provided while 85 respondents representing 21.3\% responded that between 1-4 courts were provided and 159 respondents representing $39.8 \%$ responded that above 4 volleyball courts were provided by the Local Governments Councils of Delta State. A cumulative polling (1-4 and above 4) would lead to the conclusion that a large proportion of the responses representing $61.0 \%$ showed that volleyball courts are provided to a large extent by the Local Governments.

For track and field athletics, 121 representing $30.3 \%$ agreed that no athletics facilities were provided, 131 
respondents representing $32.8 \%$ affirmed that 1-4 track and field facilities were provided and 148 respondents representing $37.0 \%$ affirmed that over 4 track and field facilities were provided by the Local Governments of Delta State. A cumulative polling (1-4 and above 4) would lead to the conclusion that above $69.7 \%$ of the population responded that athletics facilities were provided to a large extent by the Local Governments of Delta State. 383 responses representing $95.8 \%$ responded that gymnasium facilities are provided to a very low extent, 296 respondents representing $74.0 \%$ responded that swimming pools are provided to a very low extent, 337 respondents representing $84.3 \%$ responded that tennis courts are provided to a very low extent, 395 respondents representing $99.8 \%$ responded thatbadminton courts are provided to a very low extent, 400 respondents representing $100 \%$ responded that hockey pitches are provided to a very low extent, 400 respondents representing 100\% responded that cricket pitches are provided to a very low extent, 399 respondents representing $99.8 \%$ responded that facilities for disabled sports are provided to a very low extent, 136 and 160 respondents representing $34.0 \%$ and $40.0 \%$ responded that there is the provision of 1-4 and above 4 youth centres respectively. A cumulative polling (1-4 and above 4) however would lead to the accepted fact that youth centres are provided to a large extent by Local Governments Areas of Delta State, Nigeria.

Table 3: Analysis of Responses on Provision of Sports Equipment at the Local Government Areas in Delta State, Nigeria.

\begin{tabular}{|c|c|c|c|c|c|c|}
\hline \multirow{4}{*}{$\mathrm{S} / \mathrm{N}$} & \multirow{4}{*}{ Sport Equipment Provided } & & & & & \\
\hline & & \multicolumn{5}{|c|}{ Frequency Count of Responses } \\
\hline & & \multicolumn{2}{|c|}{ Nil } & \multicolumn{2}{|c|}{$1-4$} & Above 4 \\
\hline & & No. & $\%$ & No. & $\%$ & No. $\%$ \\
\hline 1 & Soccer & 11 & $(2.8)$ & 59 & $(14.0)$ & 330 (82.5) \\
\hline 2 & Basketball court & 183 & $(45.8)$ & 81 & (20.3) & $136(34.0)$ \\
\hline 3 & Volleyball & 133 & (33.3) & 78 & (19.5) & $18.9(47.3)$ \\
\hline 4 & Table Tennis & 59 & (14.8) & 83 & (20.8) & 258 (64.5) \\
\hline 5 & Hockey & 368 & $(92.0)$ & 21 & $(5.3)$ & $11 \quad(2.8)$ \\
\hline 6 & Swimming Pool & 393 & (98.3) & 3 & $(0.8)$ & (1.0) \\
\hline 7 & Lawn Tennis & 290 & $(72.5)$ & 46 & $(11.5)$ & $(16.0)$ \\
\hline 8 & Badminton & 382 & (95.5) & 11 & $(2.8)$ & (1.8) \\
\hline 9 & Cricket & 399 & (98.8) & 1 & (0.3) & $-\quad=$ \\
\hline 10 & Swimming & 277 & $(69.3)$ & 38 & (9.5) & $85 \quad(21.3)$ \\
\hline 11 & Sport for Disabled Sports & 372 & $(93.0)$ & 16 & $(4.0)$ & $(3.0)$ \\
\hline
\end{tabular}

Table 3 shows that 330 respondents representing $82.5 \%$ of the population indicated that above 4 sets of soccer equipment are provided by the Local Governments of Delta State, 59 respondents representing $14.8 \%$ responded that 14 sets of soccer equipment are provided while 11 respondents representing $2.8 \%$ responded that soccer equipment are not provided.81 respondents representing $20.3 \%$ responded that there are $1-4$ sets of basketball equipment provided while 136 respondents representing $34.0 \%$ responded that above 4 sets of basketball equipment are provided by the Local Governments of Delta State. 180 respondents representing 45.8\% responded that sets of basketball equipment are not provided. A cumulative polling however showed that $54.3 \%$ responded that $1-4$ sets and above 4 sets of basketball equipment are provided. 78 respondents representing 19.5\% responded that 1-4 sets of volleyball equipment are provided and 189 respondents representing 47.3\%responded that above 4 sets of volleyball equipment are provided by the Local Governments of Delta Statewhile 133 respondents representing 33.3\% responded that volleyball equipment are not provided. It implies then, that $66.8 \%$ of the study population affirmed that $1-4$ sets of volleyball equipment are provided. 83 and 258 respondents representing $20.8 \%$ and $64.5 \%$ respectivelyresponded that $1-4$ and above 4 sets of table tennis equipment are provided while 59 respondents representing $14.8 \%$ responded that there are no provisions of table tennis equipment by the Local Governments of Delta State.

It would be noteworthy to mention that, there is virtually an absence of equipment or where there are, the extent of provision is very low for gymnastics, hockey, tennis, badminton, cricket, swimming and sports for the disabled.

368 respondents representing $92.0 \%$ responded that there are no equipment for gymnastics, 393 respondents representing $98.3 \%$ responded that there are no equipment for hockey, 290 respondents representing $72.5 \%$ responded that there are no equipment for tennis, 383 respondents representing $95.5 \%$ responded that there are no equipment for badminton, 399 respondents representing $98.8 \%$ responded that there are no equipment for cricket, 288 respondents representing $69.3 \%$ responded that there are no equipment for swimming while 372 respondents representing $93.0 \%$ responded that there are no equipment for sports for disabled persons in the Local Government Areas of Delta State. 


\section{Conclusion}

The results show that Local Government Areas of Delta State provided facilities for soccer, athletics, basketball, volleyball general playgrounds to a high extent. The provision of equipment for soccer, basketball, volleyball and table tennis was also to a high extent. However, apart from the sports listed above, provisions of facilities and equipment for the other sports in the study were to a very low extent. It could therefore be inferred that the extent of provision of facilities and equipment by Local Governments in Delta State is low.

This affirmed the views of Gbinijie (2001) who noted that most Local Government Areas in Nigeria have no playgrounds or fields and that the Local Governments are not doing enough as would have been expected. Grassroots sports are fundamental to the success of states and national sports programmes. This low level of provision of sports facilities and equipment could mean that sports in Nigeria are standing on a weak foundation in the absence of meaningful grassroots sports development. This could also account for the dying form of school sports and the emergence of many forms of social vices, especially among youths in the urban and rural areas of Nigeria. Youths appear to no longer have useful recreation skills with an apparent lack of venues to compete in healthy conditions during school sports competitions devoid of violence.

\section{Recommendations}

Based on the results of the study, it is recommended that the Local Government Areas should:

i. make necessary efforts that are geared towards the provision of stadia and youth centres equipped with facilities and equipment

ii. Introduce rotational hosting rights of annual Local Government sports festivals in major towns within the Local Government Areas. Such hosting rights would create the need for the provision of sports facilities and equipment

iii. ensure that the Local Government Sports Committees take advantage of annually organized traditional or cultural festivals to introduce some elements of rural sports competition that could also heighten the desire for the development of communal sports facilities/equipment.

\section{References}

Bendel State (1979). The Bendel State Edict, No. 6. Benin City, Government Printing Press.

Delta State Ministry of Youth and Sports Development (2003). Progress Report on Delta State Sports Development 2001 - 2003 Data Bank.

Diejomaoh, S.O.E. (2011). Local Government Sports Development as Perceived by Sports Personnel in Delta State. Unpublished Ph.D Thesis of the Department of Physical and Health Education, Faculty of Education, Delta State University, Abraka.

Ekpe, S. (2001). Problems of Sports Development in Nigeria (Report of National Committee on Problem of Sports Development in Nigeria 3) pp 583-602.

Federal Republic of Nigeria (2009). Sports Development Policy for Nigeria.(Revised). Lagos: Federal Government of Nigeria

Gbinijie, B. (2001). Problems of Sports Development in Nigeria (Report of the Committee on Problems of Sports Development in Nigeria 3) pp 276-289

Ikhioya, O. S. (1996). Factors in camp management effectiveness of athletes optimum welfare. Journal of Nigeria Academy of Sports Administration. 4(1) pp 52-59.

Jeroh, E.J. (2012). Grassroots Sports: Conveyor Belt for Sports Development in Nigeria. AFRREV IJAH An International Journal of Arts and Humanities. Bahir Dan Ethiopia, Vol. : 265-276.

Ogbemudia, S.O. (2001). Problems of Sports Development in Nigeria (Report of National Committee on Problem of Sports Development in Nigeria 3) pp 474 - 498.

Omoruan, J.C. (1996). A Handbook on Physical Education, Sports and Recreation. Zaria. S. A. Asekome\& Co.

Onifade, A. (2000). Role of government in creating sports awareness. 21st century and sports development in Nigeria. Abuja, Federal Ministry of Sports and Social Development. Pp 128-138.

Peretomode, V. F. \& Ibeh, A. E. (1992). Basic research methods in Education and Social Sciences. Owerri, Totan Publishers Ltd.

Talabi, A.E. (1998). Poor Facilities: A Deterrent to Skill Excellence in Sports. Journal of Nigeria Academy of Sports Administration.5 (1) Pp 93-96

Whawo, D. D. (1992). Basic Educational Research and Statistics. Benin City, Samuga Publishers (Nigeria). 
